\title{
IMPLEMENTASI PENGUATAN PENDIDIKAN KARAKTER DI SMK MUHAMMADIYAH 1 MERTOYUDAN
}

\author{
Yongki Agus Prasetyo \\ Pendidikan Teknik Otomotif, Universitas Negeri Yogyakarta \\ Email: ynkagusp@gmail.com
}

\begin{abstract}
The purpose of this research is to find the implementation of improved character education $(P P K)$ at SMK Muhammadiyah 1 Mertoyudan. The indicator in this research include planning, carrying out, and evaluating a PPK Program at SMK Muhammadiyah 1 Mertoyudan. This research is a case study with a quantitative descriptive method approach. The study shows the implementation of improved character education in SMK Muhammadiyah 1 Mertoyudan a good category with a 76,26\% amount of application. The results include some indicator of a 79,97\% PPK plan, 77,41\% implementation of PPK, and 71,59\% evaluation. In the process of planning the PPK program involves all the school equipment. For performance of the PPK through the learning process, extracurricular activities, and the school's example of this it. The high point of attachment in the PPK on learners of 76,54\% in both categories. The PPK evaluation process whole school kit took part and follow up corrected some of the missing components.
\end{abstract}

Key word: Planning, Implementation, PPK Evaluation

\begin{abstract}
Abstrak
Tujuan dalam penelitian ini untuk mengetahui implementasi penguatan pendidikan karakter (PPK) di SMK Muhammadiyah 1 Mertoyudan. Indikator dalam penelitian ini meliputi Perencanaan program PPK, Pelaksanaan program PPK, dan Evaluasi program PPK di SMK Muhammadiyah 1 Mertoyudan. Penelitian ini merupakan penelitian studi kasus dengan pendekatan metode deskriptif kuantitatif. Hasil penelitian ini menunjukkan bahwa implementasi penguatan pendidikan karakter di SMK Muhammadiyah 1 Mertoyudan dalam kategori yang baik dengan tingkat ketercapaiannya sebesar 76,26\%. Hasil tersebut meliputi dari beberapa indikator yaitu perencanaan PPK sebesar 79,97\%, pelaksanaan PPK sebesar 77,41\%, dan evaluasi PPK sebesar 71,59\%. Dalam proses perencanaan program PPK melibatkan seluruh perangkat sekolah. Untuk pelaksanaan PPK melalui proses pembelajaran, kegiatan ekstrakurikuler, serta keteladanan perangkat sekolah. tingkat ketercapaian nilai utama dalam PPK pada peserta didik sebesar 76,54\% dalam kategori baik. Proses evaluasi PPK seluruh perangkat sekolah ikut terlibat dan tindak lanjutnya memperbaiki beberapa komponen yang masih kurang.
\end{abstract}

Kata kunci: Perencanaan, Pelaksanaan, Evaluasi PPK

\section{PENDAHULUAN}

Menurut data dari KPAI, jumlah kasus dalam pendidikan sampai akhir bulan Mei 2018 berjumlah 161 kasus dengan rincian korban tawuran sebanyak 23 kasus atau 14,3 persen, pelaku tawuran 31 kasus atau 19,3 persen, anak korban kekerasan dan bullying sebanyak 36 kasus atau 22,4 persen, anak pelaku kekerasan dan bullying sebanyak 41 kasus atau 25,5 persen, anak korban kebijakan berupa pungli, dikeluarkan dari sekolah, tidak boleh ikut ujian, dan putus sekolah sebanyak 30 kasus atau 18,7 persen. (sumber: www.kpai.go.id diakses pada tanggal 10 Juli 2018). Sesuai data data menunjukkan bahwa moralitas atau karakter bangsa 
Indonesia saat ini telah runtuh. Keruntuhan moralitas atau karakter bangsa telah membawa berbagai musibah dan bencana nasional negeri ini yang meluas di berbagai ranah kehidupan politik, hukum, sosial budaya bahkan keagamaan.

Persoalan yang mengancam keutuhan serta masa depan bangsa, Indonesia juga menghadapi tantangan dan persaingan di pentas global. Misalnya rendahnya indeks pembangunan individu Indonesia yang mengancam daya saing bangsa, lemahnya fisik anakanak Indonesia karena kurangnya olah raga, rendahnya rasa seni dan estetika serta pemahaman etika yang belum terbentuk selama masa pendidikan. Dari berbagai alasan tersebut telah cukup menjadi dasar yang kuat untuk menguatkan jati diri dan identitas bangsa melalui gerakan nasional pendidikan dengan meluncurkan Gerakan Penguatan Pendidikan Karakter yang diterapkan pada jenjang pendidikan dasar dan menengah tercantum dalam Perpres no. 87 tahun 2017 dan Permendikbud no. 20 tahun 2018. Urgensi penguatan pendidikan karakter untuk pembangunan SDM merupakan pembangunan bangsa, keterampilan abad 21 yang dibutuhkan peserta didik guna mewujudkan keunggulan bersaing generasi emas 2045, dan kecenderungan kondisi degradasi moralitas, etika, dan budi pekerti.

Lembaga pendidikan menjadi salah satu tempat yang efektif untuk pembentukan softskills dan hardskills seorang individu (Siswanto, Arifah, \& Ramadhan, 2019). Sejak dahulu, sekolah telah memiliki tujuan utama dalam bidang pendidikan, yaitu membentuk manusia yang cerdas dan juga memiliki watak atau karakter yang baik. Untuk mencapai tujuan tersebut, sekolah memiliki tanggung jawab yang besar dalam pendidikan karakter bagi seluruh peserta didiknya, terutama melalui disiplin, keteladanan dan organisasi sekolah.

Pola pembentukan karakter pada setiap instansi pendidikan cukup bervariasi, hal tersebut disebabkan oleh adanya perbedaan peraturan yang telah diterapkan dengan kondisi masing-masing instansi pendidikan tersebut, karena setiap instansi memiliki pembinaan, pengasuh dan peserta didik yang berbeda. Salah satu sekolah kejuruan tepatnya SMK Muhammadiyah 1 Mertoyudan, bahwa sekolah tersebut sudah melaksanakan pendidikan karakter dengan sasaran utamanya adalah peserta didik.

Namun dalam pelaksanaan masih ada beberapa kendala dari faktor peserta didik maupun lingkungan. Salah satunya masih ada indikasi peserta didik terlibat tawuran atau aksi perkelahian yang modelnya berkelompok dengan sekolah lain, selain itu masih ada yang membolos, terlambat masuk sekolah, serta beberapa peserta didik yang mengabaikan sikap sopan santun terhadap pendidik maupun perangkat sekolah. (sumber: hasil observasi dan wawancara pada tanggal 17 Juli 2018 dengan kepala sekolah dan beberapa guru). 
Oleh karena itu, penelitian ini bertujuan untuk mendeskripsikan implementasi penguatan pendidikan karakter di SMK Muhammadiyah 1 Mertoyudan. Hasil penelitian diharapkan dapat memberikan manfaat sebagai masukan untuk peningkatan pelaksanaan pendidikan karakter di SMK.

\section{METODE PENELITIAN}

Penelitian ini merupakan penelitian deskriptif studi kasus dengan menggunakan pendekatan kuantitatif. Menurut Arifin (2012: 54), penelitian deskriptif merupakan penelitian yang digunakan untuk mendeskripsikan dan menjawab persoalan-persoalan suatu fenomena yang terjadi saat ini, baik fenomena dalam variabel tunggal maupun korelasi dan atau perbandingan variabel. Penelitian dilaksanakan pada bulan Februari 2019 di SMK Muhammadiyah 1 Mertoyudan yang beralamat di dusun Santan, Sumberejo jalan Magelang-Yogya km. 5 Mertoyudan, Magelang, Jawa Tengah, Kode pos. 56172.

Dalam penelitian deskriptif ini subyek penelitian sama dengan wilayah populasi, karena subyek penelitiannya terbatas dan masih dalam jangkauan sumber daya, maka dapat dilakukan studi populasi, yaitu mempelajari seluruh subyek secara langsung (Azwar, 2010: 35). Informan/subyek dalam penelitian ini adalah kepala sekolah, waka kurikulum, waka kesiswaan, guru dan peserta didik di SMK Muhammadiyah 1 Mertoyudan. Peneliti mengambil kepala sekolah, waka kurikulum, waka kesiswaan, maupun guru, dan seluruh peserta didik sebagai responden penelitian karena informasi yang diperlukan telah diperoleh dan data yang diperoleh benar-benar valid.

Pada penelitian ini untuk mendapatkan data kuantitatif dan kualitatif, peneliti terjun langsung ke lapangan dalam mengambil data dengan menggunakan angket, pedoman wawancara, pedoman dokumentasi dan observasi. Angket berguna untuk mendapatkan data yang bersifat kuantitatif dengan informan dari guru dan peserta didik sedangkan data kualitatif diperoleh melalui wawancara, dokumentasi dan observasi.

Teknik analisis data yang digunakan dalam penelitian ini adalah analisis deskriptif kuantitatif, kualitatif dan analisa data dokumentasi. Menurut Sudjana dan Ibrahim, (2009: 126), Analisis statistik deskriptif digunakan untuk mendeskriptifkan variabel penelitian yang diperoleh melalui hasil-hasil pengukuran. Data hasil pengukuran didapatkan melalui kuisioner/angket tertutup. Dalam menentukan kedudukan dari sebuah variabel digunakan analisa deskriptif presentase. Rumus perhitungan dalam bukunya Ali (2013: 201) sebagai berikut.

$$
\%=\frac{\mathbf{n}}{N} \times 100
$$




\section{Keterangan:}

$\%=$ Presentase Pencapaian

$\mathrm{n}=$ Penjumlahan Pada Suatu Item

$\mathrm{N}=$ Penjumlahan Skor Maksimal Pada Suatu Item

Kemudian presentase yang didapat diklasifikasikan sesuai kategori pada tabel sebagai berikut ini.

Tabel 1. Kategori presentase pencapaian

\begin{tabular}{clc}
\hline No. & \multicolumn{1}{c}{ Kategori } & Nilai $(\%)$ \\
\hline 1. & Sangat Baik & $81-100$ \\
2. & Baik & $61-80$ \\
3. & Cukup & $41-60$ \\
4. & Tidak Baik & $21-40$ \\
5. & Sangat Tidak Baik & $0-20$ \\
\hline
\end{tabular}

Sumber: Riduwan (2013: 15)

Untuk analisis data kualitatif yaitu menurut Miles and Huberman dalam Sugiyono, (2015: 246) mengemukakan bahwa aktivitas dalam analisis data kualitatif dilakukan secara interaktif dan berlangsung secara terus menerus sampai tuntas, sehingga datanya sudah jenuh. Statistik deskriptif kualitatif digunakan untuk menganalisa data penelitian yang diperoleh dari angket terbuka, dan wawancara. Adapun urutannya ialah pengumpulan data, reduksi data, penyajian data, dan penarikan kesimpulan. Sedangkan analisis data dokumentasi ditujukan untuk memperoleh data langsung dari tempat penelitian yang relevan dengan variabel penelitian. Data dari hasil dokumentasi ini digunakan sebagai data pelengkap atau penguat data dari data angket.

\section{HASIL PENELITIAN DAN PEMBAHASAN}

Hasil penelitian dari implementasi penguatan pendidikan karakter terdiri dari variabel perencanaan, pelaksanaan, dan evaluasinya sebagai berikut berupa data kuantitatif dan kualitatif.

Tabel 2. Kategori hasil penelitian data yang diperoleh

\begin{tabular}{clcc}
\hline No. & Variabel & Persentase & Keterangan \\
\hline 1. & Perencanaan program PPK & $79,97 \%$ & Baik \\
2. & Pelaksanaan program PPK & $77,41 \%$ & Baik \\
3. & Evaluasi program PPK & $71,59 \%$ & Baik \\
Implementasi PPK di SMK Muhammadiyah 1 Mertoyudan & $76,26 \%$ & Baik \\
\hline
\end{tabular}


Berdasarkan hasil data diatas dapat dijelaskan bahwa perencanaan penguatan pendidikan karakter SMK Muhammadiyah 1 Mertoyudan meliputi beberapa hal yang dilakukan dalam tahap penyusunan rancangan penguatan pendidikan karakter antara lain: (1). Mengidentifikasi jenis-jenis kegiatan di sekolah yang dapat merealisasikan pendidikan karakter yang perlu dikuasai, (2). Mengembangkan materi pembelajaran dalam proses pembelajaran untuk setiap jenis kegiatan di sekolah, (3) Mengembangkan rancangan pelaksanaan setiap kegiatan di sekolah dalam bentuk jadwal maupun yang lainnya, (4) Menyiapkan fasilitas pendukung pelaksanaan program pembentukan karakter di sekolah.

Dalam pelaksanaan penguatan pendidikan karakter di SMK Muhammadiyah 1 Mertoyudan terbagi menjadi tiga bagian yaitu diinternalisasikan dalam proses pembelajaran, kemudian dalam kegiatan ekstrakurikuler, dan kegiatan pembudayaan/pembiasaan. sesuai dengan pedoman pelaksanaan pendidikan karakter Kementerian Pendidikan dan Kebudayaan, yang menyatakan bahwa kegiatan pembelajaran dari tahapan kegiatan pendahuluan, inti, dan penutup, dipilih dan dilaksanakan agar peserta didik mempraktikkan nilai-nilai karakter yang ditargetkan. Untuk kegiatan ekstrakurikuler terdiri dari ekstrakurikuler Pramuka, ekstrakurikuler olah raga, HW, seni, agama, dan belajar mengendarai mobil atau les mengemudi. Kegiatan rutin yang dilaksanakan SMK Muhammadiyah 1 Mertoyudan antara lain upacara bendera, senam bersama, berdo'a bersama, peringatan hari besar nasional, peringatan hari besar Agama, Jum'at bersih dan piket kelas. Kegiatan insidental yang dilaksanakan SMK Muhammadiyah 1 Mertoyudan antara lain penggalangan dana, kebersihan lingkungan di masyarakat, maupun partisipasi dalam seminar dan lain sebagainya. Kegiatan pengkondisian dan keteladanan yang dilakukan SMK Muhammadiyah 1 Mertoyudan antara lain lingkungan sekolah menciptakan budaya yang bersih dan kondusif sehingga tercipta suasana yang aman dan nyaman bagi semua warga sekolah maupun keteladanan pendidik dan karyawan/perangkat sekolah dalam memberikan teladan yang baik. Sedangkan tingkat keterlaksanaan nilai-nilai utama dalam penguatan pendidikan karakter yang terukur dari peserta didik melalui angket tertutup sebesar 76,54\% pada kategori yang baik.

Dalam proses evaluasi program penguatan pendidikan karakter di SMK Muhammadiyah 1 Mertoyudan tahapan pertama yaitu pembentukan tim evaluasi namun untuk tim evaluasi belum ada masih ditanggung jawabkan pada bagian BK. Setelah terbentuk tim tentu dilanjutkan dengan perumusan indikator program PPK untuk proses pengumpulan data. Indikator program sesuai dengan rancangan yang telah disusun sebelumnya dalam proses perencanaan. Indikator untuk program PPK yang terintegrasi dalam kegiatan belajar mengajar disesuaikan dengan indikator penilaian sikap yang termuat dalam RPP. Sementara untuk 
program PPK yang terintegrasi dalam kegiatan di luar pembelajaran, indikatornya disesuaikan dengan program-program terkait yang semuanya tertuang dalam buku saku tata tertib.

Pada proses pengumpulan data dilakukan dengan cara analisa pelaksanaan program, pengamatan perubahan tingkah laku anak, laporan pengamatan perilaku karakter peserta didik, dan penilaian lewat penskoran. Dalam program PPK yang terintegrasi dengan proses pembelajaran, pendidik melakukan penilaian secara kognitif dan afektif yang mengacu dalam nilai-nilai pendidikan karakter menggunakan pedoman penilaian yang telah disusun sebelumnya dalam perencanaan pembelajaran. Namun dalam penilaian tidak bisa secara objektif satu persatu melainkan hanya dinilai karakter peserta didik yang paling menonjol baik menonjol dalam arti positif maupun menonjol dalam arti negatif. Pedoman evaluasi ini terdapat satu lembar tersendiri mengenai lembar pengamatan penilaian sikap.

Kemudian untuk evaluasi program PPK di luar pembelajaran dilakukan melalui analisa pelaksanaan program melalui rapat kerja guru/pendidik, pengamatan perubahan tingkah laku anak/peserta didik, laporan pengamatan perilaku karakter peserta didik, dan penskoran yan semuanya tertuang dalam buku tata tertib SMK Muhammadiyah 1 Mertoyudan. Setiap terjadi pelanggaran maka peserta didik yang melakukan pelanggaran akan mendapat poin dari guru sesuai dengan jenis pelanggaran yang dilakukan.

Setelah berbagai data tersebut terkumpul maka dilakukan pengolahan. Dari hasil olahan data mengenai pelaksanaan program PPK kemudian disimpulkan dan dilakukan tindak lanjut. Untuk tindak lanjut dari proses evaluasi yaitu melakukan berbagai pembenahan program PPK, memaksimalkan berbagai daya dukung, menjalin kekompakan antar personil untuk memperbaiki kekurangan program PPK yang sebelumnya, serta dikeluarkannya sertifikat kelakuan baik untuk para lulusan.

Pada intinya evaluasi program PPK di SMK Muhammadiyah 1 Mertoyudan telah dilaksanakan dan berjalan walaupun secara administrasi mengenai instrumen evaluasi belum disusun secara tertulis tetapi dalam evaluasi PPK dilakukan secara lisan. Sedangkan penilaian sikap peserta didik bisa dilihat dengan adanya lembar pengamatan penilaian sikap peserta didik atau lembar poin pelanggaran yang termuat dalam buku tata tertib peserta didik dalam evaluasi penguatan pendidikan karakter di SMK Muhammadiyah 1 Mertoyudan.

\section{SIMPULAN}

Dalam tahap perencanaan penguatan pendidikan karakter menyatakan tanggung jawab/wewenang utama dalam merencanakan program PPK adalah guru BK namun tetap diberi arahan oleh kepala sekolah. Kemudian peran perangkat sekolah cukup baik artinya ikut 
berpartisipasi secara aktif dalam proses perencanaan program tersebut. Prinsip sekolah dalam perencanaan program PPK yaitu sesuai dengan visi dan misi sekolah seperti tujuan utama untuk menghasilkan peserta didik yang berkepribadian baik. Pada tahap pelaksanaan penguatan pendidikan karakter SMK Muhammadiyah 1 Mertoyudan seluruh perangkat sekolah ikut terlibat dan membantu dalam pelaksanaan. Seperti pendidik dalam proses pembelajaran menerapkan pembelajaran aktif dan selalu menanamkan nilai-nilai karakter ke peserta didik. Selain pendidik perangkat sekolah yang lain harus menunjukkan sikap keteladanan yang baik di sekolah maupun di luar sekolah. Disisi lain untuk mendukung program tersebut maka sumber dana diambil dari BOS maupun lembaga-lembaga diluar sekolah. Untuk proses evaluasi dibahas berbagai permasalahan maupun tingkat keterlaksanaan program PPK di sekolah sesuai dengan data yang diperoleh. Tindak lanjut setelah proses evaluasi yaitu penambahan dari berbagai komponen yang masih kurang secara langsung maupun bertahap.

Dalam perencanaan pendidikan karakter sebaiknya diawali dengan sosialisasi dengan menghadirkan ahli yang kompeten dalam bidang pendidikan karakter. Sekolah mengintegrasi tidak semua butir nilai-nilai karakter tetapi beberapa nilai utama saja. Tetap menunjukkan komitmen yang tinggi untuk senantiasa melakukan inovasi-inovasi yang baru. Terus berupaya membangun komunikasi dan melakukan kerjasama dengan pihak-pihak terkait (tokoh masyarakat, pengawas sekolah dan pemerhati pendidikan) untuk terus berupaya mencari dan mengembangkan pendidikan karakter guna memajukan sekolah tersebut.

\section{DAFTAR PUSTAKA}

Ali, M. (2013). Penelitian Kependidikan Prosedur dan Strategi. Bandung: Angkasa.

Arifin, Z. (2012). Penelitian Pendidikan Metode dan Paradigma Baru. Bandung: Remaja Rosdakarya.

Azwar, S. (2010). Metode Penelitian. Yogyakarta: Pustaka Pelajar.

Peraturan Presiden Nomor 87 Tahun 2017 Tentang Penguatan Pendidikan Karakter.

Peraturan Kementerian Pendidikan dan Kebudayaan Nomor 20 Tahun 2018 Tentang Penguatan Pendidikan Karakter pada Satuan Pendidikan Formal.

Riduwan. (2013). Skala Pengukuran Variabel-Variabel Penelitian. Bandung: Alfabeta.

Siswanto, I., Arifah, I. W. N., \& Ramadhan, F. E. N. (2019). Pengaruh Keaktifan di Organisasi dan IPK terhadap Softskills dan Kesiapan Menjadi Guru Mahasiswa Pendidikan Teknik Otomotif. TAMAN VOKASI, 7(2), 106-115.

Sudjana, N \& Ibrahim. (2009). Penelitian dan Penilaian Pendidikan. Bandung: Sinar Baru Algresindo.

Sugiyono. (2015). Metode Penelitian Kuantitatif, Kualitatif, dan R\&D. Bandung: Alfabeta. 
66 Yongki Agus Prasetyo

www.kpai.go.id diakses pada tanggal 10 Juli 2018. 